\title{
Crime Investigation on Theft by eighting with The Modus Of Prying Automated Teller Machine (ATM) in Jurisdiction Area of Central Java
}

\author{
Mohamad Rofiqi ${ }^{1}$ and Anis Mashdurohatun ${ }^{2}$
}

Abstract. This study aims to: 1) Review and analyze the implementation of the criminal investigations against theft by weighting with the modus of prying Automated Teller Machine (ATM) in the jurisdiction area of Central Java. 2) Assess and analyze the factors that hinder the investigation related to solve investigator in the criminal investigations against theft by weighting with the modus of prying Automated Teller Machine (ATM) in the jurisdiction area of Central Java. 3) Assess and analyze the efforts of investigators linked the criminal investigations against theft by weighting with the modus of prying Automated Teller Machine (ATM) in the jurisdiction area of Central Java? Results: 1). The process of investigations conducted by the Central Java Police in solving criminal cases of theft through Automated Teller Machine (ATM) with prying mode in accordance with the rules contained in the Criminal Procedure Code and the Law on Police No. 2 of 2002. 2). Based on the description of the Central Java Police investigators, the obstacles faced by the team of investigators of Central Java Police, among others: a. Evidence is hidden and difficult for investigators to look suspect. b. The suspect managed to flee with his colleagues by car, so investigators have to chase. c. In providing information with convoluted.3) Relatedwith efforts to overcome obstacles investigator in a criminal law enforcement ATM theft with prying mode is as follows: a. In search of evidence of the crime of investigators need to conduct more intensive searches of suspects. b. Coordinating with other entities by way of exchange of information / Data notify each DPO (List of People Searching) and when in the area to find people who sought immediately apprise and made arrests. c. Providing information (by extension agents) to the public to participate actively in supporting the work of police in the investigation of the theft through ATM.

Keywords: Investigation; Crime of Theft By Weighting; Prying Automated Teller Machine (ATM).

\section{Introduction}

Crime through the Automated Teller Machine (ATM) is one of many kinds such as theft, robbery, fraud, burglary and others. Modus crimes involving ATMs that have occurred in the region of Central Java Police ie ATM burglary. The perpetrators broke into the ATM machine (either prying in place, by the way pried or even steal their engines at once).

\footnotetext{
${ }^{1}$ Student of Master of Law, Universitas Islam Sultan Agung Semarang and Ditreskrimum Polda Jateng Email: mohammadrofiqi26@gmail.com

${ }^{2}$ Lecturer of Faculty of Law UNISSULA Semarang
} 
Criminal law in the form of written rules were formulated, created and enacted for the enactment of a positive law (ius constitutum), but it will be effective and perceived can achieve fairness and legal certainty if the application in accordance with what was intended by the legislators as to what it says in sentences. Criminal law should be maintained as a means for social defense in a sense protect the public against crime by repairing or restoring (rehabilitatie) the maker without reducing the balance of interests. Detailed arrangements regarding the crime of theft in the Criminal Code is in Chapter XXII of theft. Article 362 of the Criminal Code. ${ }^{3}$

Based on the foregoing, the writer interested to study the problems with the title, the criminal investigations against theft by weighting with the modus of prying Automated Teller Machine (ATM) in the jurisdiction area of Central Java. Based on the above description meal formulation of the problem in this research is: How is the implementation of the criminal investigations against theft by weighting with the modus of prying Automated Teller Machine (ATM) in the jurisdiction area of Central Java?; What are the factors that hinder the investigation related to the criminal investigations against theft by weighting with the modus of prying Automated Teller Machine (ATM) in the jurisdiction area of Central Java? How well as the criminal investigations against theft by weighting with the modus of prying Automated Teller Machine (ATM) in the jurisdiction area of Central Java?

\section{Research Methods}

Approach the problem in this research using normative juridical approach and empirical juridical approach. Normative juridical approach to fully understand the issue by staying on or relied on the courts or the study of jurisprudence, while the juridical empirical approach taken to achieve clarity and understanding of the research problem based

This type of research is used in completing this research is descriptive analysis juridical research method, the research done by researching library materials (secondary data) or legal research library ${ }^{4}$ and described in the analysis and discussion.

The data used are primary and secondary data. To obtain primary data researchers refer to data or facts and case law directly obtained through research in the field, including a description of the respondents. While the secondary data is done by means of a literature study.

Secondary data in this study include: Material primary law, which consists of: the Constitution of the Republic of Indonesia of 1945, the Code of Penal, Act No. 2 of 2002 on the Indonesian National Police, Act No. 1 In 2009 on the Use of Force, Act No. 8 of 1981 on Criminal Proceedings, Indonesian Police Chief Regulation No. 14 of 2011 on the Police ethics Code, Criminal Code draft 2017 Chapter XXVI on the Crime of Theft. Secondary legal materials include books, journals, and documents the results of research in the field of law, especially the problem of implementation of the police discretionary authority in dealing with cases of theft by weighting.

\footnotetext{
${ }^{3}$ Andi Hamzah.2005 Hukum Acara Pidana Sinar Grafika Jakarta p. 70

${ }^{4}$ Ediwarman 2010 Monograf Metodologi Penelitian Hukum Medan: Program Pascasarjana Univ. Muhammadiyah Sumatera Utara Medan p. 24
} 
Tertiary legal material, comprising: Indonesian Dictionary, English Dictionary, the Law Dictionary, Encyclopedia and the means of teaching (hand out) about the manner of writing scientific papers.

The data collection is focused on the present, so that in this study is not distorted and blurred in the discussion. Literature study, this research using the Library Research (literature study) that the collection of data obtained from sources of literature, scientific papers, legislation and other written sources relating to the matter being investigated as a theoretical basis. Field studies, data collection techniques used in this study to obtain the data is done by observation and interview.

Interviews were conducted dengna How Free Guided. In a free guided interview, the interviewer combines free interviews with guided interviews, which in practice is the interviewer has brought guidance on what is asked in outline.

In this study, the authors took samples using Non-Random Sampling technique is a sampling technique does not provide equal opportunities in every subject population for the research sample ${ }^{5}$.

Data analysis method used is descriptive qualitative, ie the decomposition of data analysis that starts on information obtained from the respondents to achieve clarity issues to be discussed ${ }^{6}$.

\section{Results and Discussion}

2.1. Implementation of the the criminal investigations against theft by weighting with the modus of prying Automated Teller Machine (ATM) in the jurisdiction area of Central Java

Legal actions that may be taken by the Central Java Police investigator refers to Article 7 of the Book of Criminal Law (Criminal Code). As for the investigation of the offenses of theft through ATM by the Central Java Police investigators are as follows:

- Receiving Reports

- Take Action First

- Arrest and Detention

- Foreclosure

- The suspect and witness examination

- completion of Investigation

It can be concluded that the Central Java Police investigations conducted in resolving criminal cases of theft through Automated Teller Machine (ATM) with prying mode in accordance with the rules contained in the Criminal Procedure Code and the Act on Police No. 2 of 2002.

\subsection{What are the Inhibiting Factors Related the criminal investigations against theft by weighting with the modus of prying Automated Teller Machine (ATM) in the jurisdiction area of Central Java}

Disclosure of ATM theft case with prying mode in the region of Central Java Police, the

\footnotetext{
${ }^{5}$ Arikunto Suharsimi. 2002. Prosedur Penelitian Suatu Pendekatan Praktek. Rineka Cipta Jakarta p. 265

${ }^{6}$ Afifuddin dkk 2009. Metodologi Penelitian Kualitatif. Pustaka Setia. Bandung p. 15
} 
Central Java Police investigators and investigators encounter obstacles in uncovering this theft. According to the Central Java Police investigators, the obstacles faced by the team of investigators and investigators Central Java Police, among others:

- Evidence of crime are hard to find due to the alleged offender is hidden and difficult for investigators to look for.

- The suspect managed to flee with his colleagues by car, so investigators have to chase.

- In providing their testimony convoluted.

- The proceeds of crime is up used suspects and colleagues.

- The perpetrator in the younger age groups in sedentary activities and have a network outside the city so that the disclosures or arrest the perpetrators are often not completely (only partially captured).

- Participants not provide support for the provision of information regarding criminal acts of theft through ATM and identity of the perpetrators to the police.

- Facilities and infrastructure officer in conducting investigations and inquiries were inadequate.

2.3. Efforts Related to the criminal investigations against theft by weighting with the modus of prying Automated Teller Machine (ATM) in the jurisdiction area of Central Java

Related to efforts to overcome obstacles investigator in a criminal law enforcement ATM theft with prying mode is as follows:

- In search of evidence of the crime of investigators need to conduct more intensive searches of suspects.

- Coordinating with other entities by way of exchange of information / Data notify each DPO (List of People Search) and when in the area to find people who sought immediately apprise and made arrests.

- Providing information (by extension agents) to the public to participate actively in supporting the work of police in the investigation of the theft through ATM.

- Using the existing infrastructure with the principle remains improving professional performance in order to serve the community.

- Call for employee selection and tighten banking security systems are constantly updated. Technological developments with their ATMs are located in different places often invite the parties are not responsible for the abuse.

- In addressing the shortage or lack of facilities and infrastructure in uncovering crimes. Thus the need to include adequate facilities and infrastructure to accelerate and facilitate the process of investigation or inspection.

\section{Closing}

\subsection{Conclusion}

- The process of investigations conducted by the Central Java Police in solving criminal cases of theft through Automated Teller Machine (ATM) with prying mode 
in accordance with the rules contained in the Criminal Procedure Code and the Act on Police No. 2 of 2002.

- Based on the description of the Central Java Police investigators, the obstacles faced by the team of investigators and investigators Central Java Police, among others:

- Evidence in criminal proceeds are hard to find.

- The suspect managed to flee with his colleagues.

- In providing information with convoluted.

- The proceeds of crime is up used suspects.

- Actors in the younger age groups in sedentary activities and have a network outside the city so that the disclosures or arrest the perpetrators are often not completely (only partially captured).

- Less community to provide support for the provision of information regarding criminal acts of theft through ATM and identity of the perpetrators to the police.

- Facilities and infrastructure officer in conducting investigations and inquiries were inadequate.

- Related to efforts to overcome obstacles investigator in a criminal law enforcement ATM theft with prying mode is as follows:

- In the search for evidence of the crime of investigators need to conduct more intensive searches of suspects.

- To coordinate with other entities by way of exchange of information / Data notify each DPO (List of People Search) and when in the area to find people who sought immediately apprise and made arrests.

- Provide counseling (by extension agents) to the public to participate actively in supporting the work of police in the investigation of the theft through ATM.

- Using the existing infrastructure with the principle remains improving professional performance in order to serve the community.

- Call for employee selection and tighten banking security systems are constantly updated.

- In addressing the shortage or lack of facilities and infrastructure in uncovering cases of crimes it is necessary to include adequate facilities and infrastructure to accelerate and facilitate the process of investigation or inspection.

\subsection{Suggestion}

- Necessary action to anticipate all sorts of possibilities that will arise impede the course of the investigation process, so it needs the necessary rigor and foresight in this case.

- It is necessary fabric of coordination between unity with one another. Can also be done by inviting public participation around the ATM machine to report any suspicious activity to the police.

\section{Bibliography}

[1] Andi Hamzah 2005 Hukum Acara Pidana Sinar Grafika Jakarta 
[2] Arikunto Suharsimi 2002 Prosedur Penelitian Suatu Pendekatan Praktek Jakarta: Rineka Cipta.

[3] Soerjono Soekanto 2005. Pengantar Penelitian Hukum Jakarta : Rineka Cipta.

[4] Ediwarman 2010 Monograf Metodologi Penelitian Hukum Medan: Program Pascasarjana Univ. Muhammadiyah Sumatera Utara Medan.

[5] Afifuddin dkk 2009 Metodologi Penelitian Kualitatif Pustaka Setia Bandung

[6] Constitution of the Republic of Indonesia of 1945.

[7] The Code of Criminal Procedure

[8] Act No. 2 of 2002 on the Indonesian National Police.

[9] Act No. 1 of 2009 on the Use of Force.

[10] Act No. 8 of 1981 on Criminal Proceedings

[11] Indonesian Police Chief Regulation No. 14 of 2011 on the Police Code of Conduct.

[12] Criminal Code draft of 2017 Chapter XXVI of the Crime of Theft 